\title{
开拓创新 追求卓越 建设一流研究型大学
}

五十载春华秋实, 半世纪岁月如歌. 中国科学技术大学刚刚度过了她的 50 岁生日. 胡锦涛总书 记专门发来贺信, 希望中国科学技术大学进一步增强使命感和责任感, 瞄准世界科技前沿, 服务国家 发展战略, 创造性地做好教学和科研工作, 努力办成世界一流的研究型大学.

作为新中国自己创办的一所新型理工科大学, 中国科学技术大学从 1958 年建校以来, 始终与祖 国同呼吸, 共命运, 始终秉承“创新立校、科教报国”的办学理念, 弘扬“红专并进, 理实交融”的优良校 风, 按照首任校长郭沫若提出的“既出人才, 又出成果” 的要求, 追求卓越, 走出了一条独立自主、 创新发展的精品办学之路, 培养了一大批高层次优秀人才, 取得了一系列具有世界先进水平的原创 性科技成果, 为推动我国科教事业发展和社会主义现代化建设做出了重要贡献.

建校伊始, 中国科学技术大学就瞄准“两弹一星”为代表的国家重大战略需求, 在空白和新兴科 技领域内设置系科专业, 由中国科学院著名科学家亲自上课, 实施教学与科研相结合、科学与技术相结 合、理论与实践相结合的创新举措, 注重基础课教学, 高起点、宽口径培养新兴、边缘、交叉学科的 尖端科技人才. 改革开放初期, 中国科学技术大学在全国率先提出并实施一系列具有创新精神和前 瞻意识的教育改革措施, 首创少年班, 推行学分制, 创办全国第一个研究生院, 建设高校中唯一的国 家大科学工程, 引领中国高等教育改革风气之先. 20 世纪 90 年代中期以来, 学校相继实施国家“ 211 工程”、“985 工程”和“知识创新工程”, 面向国家需求积极实施教育教学改革, 探索出创新型人才 培养的新模式, 追踪世界科学技术前沿, 调整学科结构, 在量子信息、纳米科技、生命科学等学科领 域取得了显著进展, 培养了一大批各领域的优秀人才、领军人物.

中国科学技术大学的 50 年发展历程很不平凡，她书写了中国高等教育史上的亮丽篇章. 作为一 所研究型大学, 她在科学技术研究方面也取得了长足的进步. 为了庆祝中国科学技术大学建校 50 周 年, 报道她近年来的学术研究进展, 受《科学通报》主编夏建白院士约请, 我们组织了国家同步辐射 实验室、合肥微尺度物质科学国家实验室(筹)、火灾科学国家重点实验室、国家高性能计算中心 (合肥)和蒙城地球物理国家野外科学观测研究站等重点研究机构的骨干研究人员和一些院系的知名 教授为《中国科学技术大学专辑》撰写论文. 专辑分为中、英文两个版本出版, 将分别发表中文稿 27 篇, 英文稿 25 篇. 这些论文反映了中国科学技术大学近年来在量子信息、单分子科学、高温超导、 纳米科技、生命科学、火灾科学、高性能计算、地球与环境科学、新能源等领域的研究进展.

《科学通报》是我国自然科学基础研究领域里权威性的学术刊物, 曾经发表过大量高水平的重要 研究成果, 为加强国内外学术交流、促进我国科研事业的发展做出了积极贡献. 今天, 我们借助《科学 通报》这个平台, 推出这期专辑, 期望能够从独特的学术视角展示中国科学技术大学的形象, 打开一扇 方便海内外读者进一步了解中国科学技术大学的窗口, 争取海内外读者对中国科学技术大学的更多 关注.

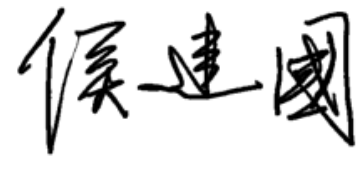

中国科学技术大学校长中国科学院院士 二○○九年四月 